\title{
Ocean Views: Coastal Environmental Problems as Seen by Downeast Maine Residents
}

\author{
THOMAS G. SAFFORD AND LAWRENCE C. HAMILTON
}

$\mathrm{T}$ Through the Community and Environment in Rural America (CERA) initiative, Carsey Institute researchers have conducted surveys in selected regions across the United States. The goal is to learn how a broad cross section of Americans view the social and environmental changes affecting their lives and rural communities. We report here on the environmental views of 1,500 residents in two rural counties along the northeast coast of Maine. This region has historically depended on fisheries and forestry but more recently has experienced growth in tourism and second homes, making both traditional and new economic activities dependent on environmental conditions.

Most respondents express at least some concern about the impact on their family or community of environmental problems, such as pollution of beaches, contamination of seafood, depletion of fishery resources, and rising sea levels. Across a wide range of environmental issues, political party affiliation is associated with level of concern about environmental problems. Nonetheless, some degree of consensus exists over government responses to these problems. In a question asking whether the government should be doing more or less to regulate commercial fishing and lobstering, the most common answer was that government regulators should "leave the rules as they are"-even among those who work in the fishing industry. These findings suggest that managers and public officials should consider ways to more effectively use existing regulations to address coastal environmental problems while supporting the communities that depend on marine resources for their economic and social well-being.

\section{The Changing Face of Rural Coastal Communities}

From the Atlantic to the Pacific, coastal regions of the United States are coping with dramatic social and environmental changes. Coastal counties are home to 53 percent of the nation's population, yet, excluding Alaska, they account for only 17 percent of land area in the United States. ${ }^{1}$ Nonethe-

\section{Key Findings:}

In August and September 2009, Carsey Institute researchers surveyed 1,500 residents of northeastern (Downeast) Maine about coastal environmental issues and government efforts to address them. Key findings include the following:

- Loss of fishing jobs or income ranks highest among environment-related issues affecting the respondents' communities (Figure 1).

- Water pollution, loss of forestry jobs, sprawl or rapid development of the countryside, and climate change also rank high (Figure 1).

- The coastal environmental problems that most concern Downeasters are pollution of beaches or shellfish beds, contamination of seafood, and overfishing (Figure 2).

- Most respondents express some concern about environmental issues, but a significant partisan division exists. Across all issues, those who self-identify as Republicans are less concerned than Democrats or Independents (Figure 3).

- Regarding government regulation of commercial fishing or lobstering, more people of all political persuasions favor leaving the rules as they are rather than regulating either more or less (Figures 4-5).

less, most of this population is concentrated near urban centers, and a significant portion of America's coast retains its rural character. The desirability of living and vacationing on the coast has made these rural areas targets for development, drawing new residents and economic activities to previously isolated communities.

Alongside these demographic and economic shifts have come alterations in coastal and marine environments. Changing ocean and climate conditions, together with inad- 
equate management strategies, have led to sharp declines in harvestable marine resources. In addition, expanding development has damaged sensitive estuarine and coastal habitats, while both air- and waterborne pollutants have impaired the aquatic ecosystems on which human and biological communities depend. ${ }^{2}$ Policy makers and community leaders struggle to find adequate responses to the scale, complexity, and speed of these changes. Understanding how residents of rural coastal communities view these emerging social and environmental problems will help to inform both governance and management decision making.

Since 2007, researchers at the Carsey Institute of the University of New Hampshire have been investigating these types of changes through the CERA initiative. The CERA research team is conducting surveys and analyzing socioeconomic and environmental trends to better understand common patterns across rural America. A key goal of this effort is to provide decision makers and community organizations with information that can assist in promoting social and environmental resilience.

CERA's initial stages in 2007 and 2008 included randomsample telephone surveys with 8,800 residents in twenty-four rural counties in ten states across America. ${ }^{3}$ In the summer of 2009, Carsey researchers began a new phase, looking specifically at coastal communities. As a first step, we surveyed 1,500 residents of two rural coastal counties (Hancock and Washington) in Maine to gauge their views on social and environmental conditions in their region. This policy brief presents initial findings from the survey, highlighting important patterns in community perceptions of economic changes, marine environmental issues, and potential policy solutions.

\section{The Social Importance of Marine Resources in Maine}

The coast of Maine is a microcosm of broader social and environmental change in rural coastal communities across the United States. The two easternmost counties, Hancock and Washington, make up what is known locally as Downeast Maine. This region is composed primarily of small towns scattered along the coast and neighboring islands. In 2008, the population of Hancock County was 53,137, while Washington County's population was $32,499 .{ }^{4}$ Current economic conditions in this area are mixed. In 2008, 12.6 percent of Maine residents lived below the poverty line. In comparison, Washington County had the most severe poverty in the state, with 19.4 percent of the population living below the poverty line, while Hancock County fell slightly below the state average at 10.0 percent. $^{5}$

Historically, fishing and marine commerce have been the lifeblood of the Downeast region. Today they represent a decreasing share of the economy, but the docks and fish- ing boats along the shore are emblematic of coastal Maine's identity. Rapid increases in tourism, declining fisheries, and growing threats from pollution are bringing both social and environmental change to Downeast towns and villages. Figure 1 outlines Hancock County and Washington County residents' views of how an array of environment-related issues have affected their communities.

Figure 1: HAVE THESE ENVIRONMENTAL ISSUES HAD NO EFFECT, MINOR EFFECTS, OR MAJOR EFFECTS ON YOUR FAMILY OR COMMUNITY OVER THE PAST FIVE YEARS?

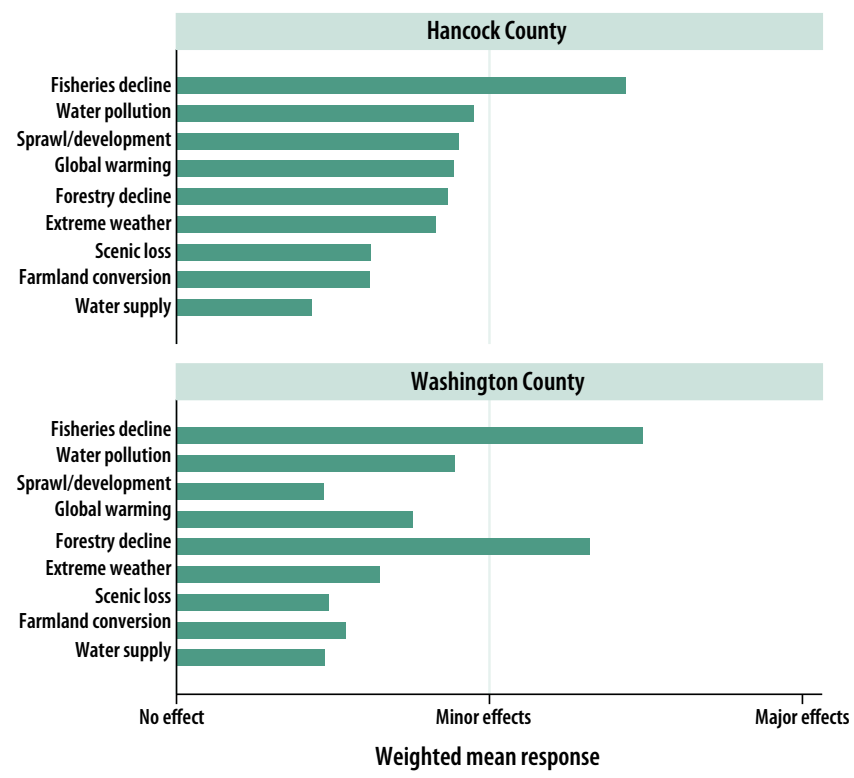

Figure 1 shows that people from both counties most frequently cited "loss of fishing jobs or income" as an issue affecting their family or community. Among Washington County respondents, where forestry remains an important part of the economy, "loss of forestry jobs or income" came in a close second to fisheries. Survey responses indicate that water pollution and the impacts of sprawl and development also are substantial concerns, particularly in Hancock County where scenic areas around Acadia National Park have fueled growth in tourism and new housing development.

Maine has the highest percentage of housing units classified as second homes (15.6 percent) in the United States. ${ }^{6}$ Although most seasonal homes are in southern Maine near metropolitan centers, second homes are becoming widespread in the more distant Downeast counties as well. Of the state's sixteen counties, Hancock is among the three fastest growing, driven partly by second-home development. The county now has more than 10,000 seasonal housing units. ${ }^{7}$ Washington County remains one of the areas least affected by this trend, but interest in coastal properties has meant that even in this remote coastal area of Maine, the effects of development are arriving. The survey results show that residents of both counties are concerned with declines in 
traditional extractive industries and changing patterns of development, which have implications for how they view marine environmental concerns and policy responses.

\section{The Social and Environmental Implications of Economic Change in Coastal Maine}

Local concern about the loss of fishing jobs and pollution effects on water resources reflects changing socioeconomic and environmental conditions in Hancock and Washington counties. Maine's fishing industry has declined dramatically in the past thirty years, and the declines have been especially difficult for rural Downeast communities, which are considered to be the most fishery-dependent in all of New England. ${ }^{8}$ Cod harvests, one of Maine's most important commercial species, have fallen in value from over $\$ 16$ million in 1991 to $\$ 3.7$ million in 2008. Sea scallops have declined from $\$ 15$ million in 1981 to $\$ 1.2$ million in $2007 .{ }^{9}$ Depletion of fish resources is considered a serious problem. In New England, numerous fish stocks, such as Georges Bank cod, have been found to be overfished and in need of rebuilding. ${ }^{10}$ Internationally, the United Nations Food and Agriculture Organization reports that 52 percent of fisheries stocks worldwide are "fully exploited," meaning no expansion is possible without collapsing the resource, and a further 27 percent are overexploited, depleted, or recovering from overexploitation. ${ }^{11}$

Although the most severe drops in fish harvests occurred in the late 1990s, the last three years have seen continued steady declines in both Hancock and Washington counties. ${ }^{12}$ Even lobster, which has been Downeast Maine's most stable fishery, has declined both in pounds caught and total value from 2006 to 2008. ${ }^{13}$ Although the number of vessels and individuals involved in fishing has stabilized in recent years, overfishing remains a concern. Federal, state, and local government officials have struggled to find methods for managing fisheries that meet the needs of fishing communities while also sustaining marine ecosystems.

As fishing in Downeast Maine declines, other coastal and ocean-related enterprises have become increasingly important. The scenic beauty of the coast attracts thousands of visitors to the region, and tourism is now one of the most important industries in eastern Maine. Hancock and Washington counties have also experienced significant growth in both salmon and shellfish aquaculture. This industry has brought needed revenue and jobs to the fishing sector. However, studies have uncovered new environmental problems resulting from the effluent of fish farming operations. ${ }^{14}$ In addition, some residents and coastal towns have raised questions about whether aquaculture operations might affect the scenic qualities of the area and thus impact tourism.
Pollution from aquaculture operations is not the only environmental problem in coastal Maine. Many scientific reports, from local to global in scale, have documented worrisome levels of mercury, dioxin, and other contaminants in fish and the potential health effects on humans. ${ }^{15}$ Contaminants such as PCBs, dioxin, and mercury have been found in ocean fish, such as striped bass, bluefish, and tuna. ${ }^{16}$ Red tide algal blooms, linked to changing climatic conditions, have affected commercial and recreational shellfish harvesters across the state. In Downeast Maine, concerns about waterborne pollutants have led to closures of shellfish beds and affected aquaculture operations. ${ }^{17}$ These pollution issues are important concerns in small communities that rely heavily on harvesting blue mussels, quahogs, periwinkles, and soft-shell clams. ${ }^{18}$

The CERA survey asked several questions to assess the extent of concern among Downeast residents regarding these emerging marine issues (Figure 2).

FIGURE 2: WOULD YOU SAY THAT YOU ARE CONCERNED ABOUT THESE OCEAN-RELATED ISSUES HARDLY AT ALL, JUST SOME, A GOOD AMOUNT, OR A GREAT DEAL?

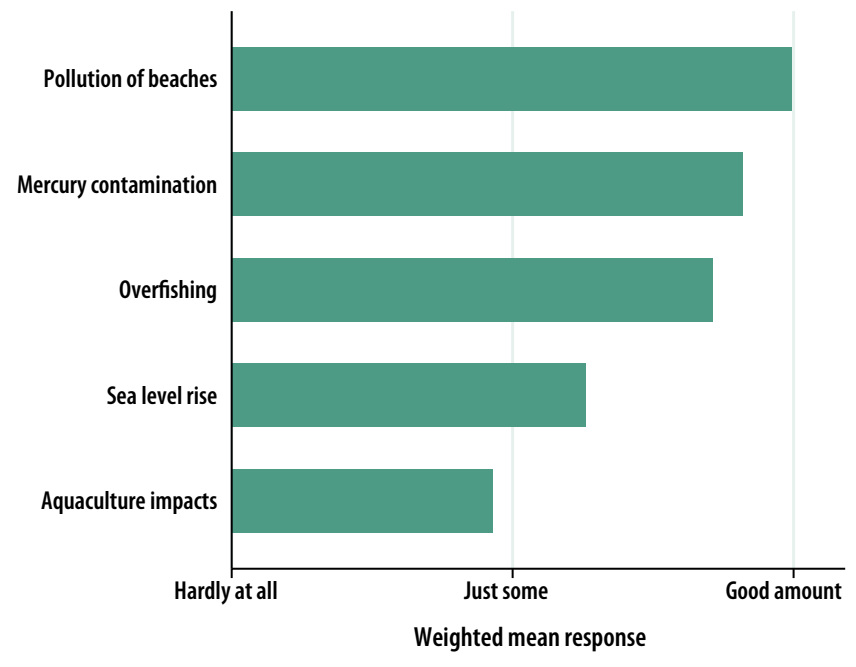

The greatest concern among those surveyed is pollution's impact on beaches and clam beds followed by contamination of seafood and depletion of fisheries by overfishing. Rising sea levels due to global warming worries fewer people. Adverse impacts of fish farming ranks lowest among the possible problems we posed to respondents. Concern about overfishing tends to be greater among residents of coastal than inland towns, likely reflecting the connections of these communities to fishing. Hancock County residents are generally more concerned than those from Washington County about the other marine issues in Figure 2. This finding may in part reflect the larger number of tourism-related businesses in Hancock County, which could be heavily affected by adverse environmental changes. 
The CERA team also examined whether different segments of these communities share similar levels of concern. For example, we consistently found political party preference to be the strongest predictor of concern about environmental issues. Earlier CERA surveys had, less surprisingly, detected partisan divisions over the nationally debated topic of global warming. However, we did not expect to find similar divisions on more local topics, such as beach pollution or seafood contamination in Downeast Maine. A clear partisan pattern nevertheless emerges across all five of our ocean-related issues. On each issue, Republicans express lower levels of concern than Independents or Democrats do, as seen in Figure $3 \mathrm{a}-\mathrm{e}$. For comparison, Figure $3 \mathrm{f}$ depicts responses to a general question about global warming, another environmental challenge that, through weather, sea level, and ecosystem effects (including fishery declines and red tides), could impact these coastal communities substantially in the future.

FIGURE 3A-E: WOULD YOU SAY THAT YOU ARE CONCERNED ABOUT THESE OCEAN-RELATED ISSUES HARDLY AT ALL, JUST SOME, A GOOD AMOUNT, OR A GREAT DEAL?

Figure 3A: Pollution of beaches and clam beds

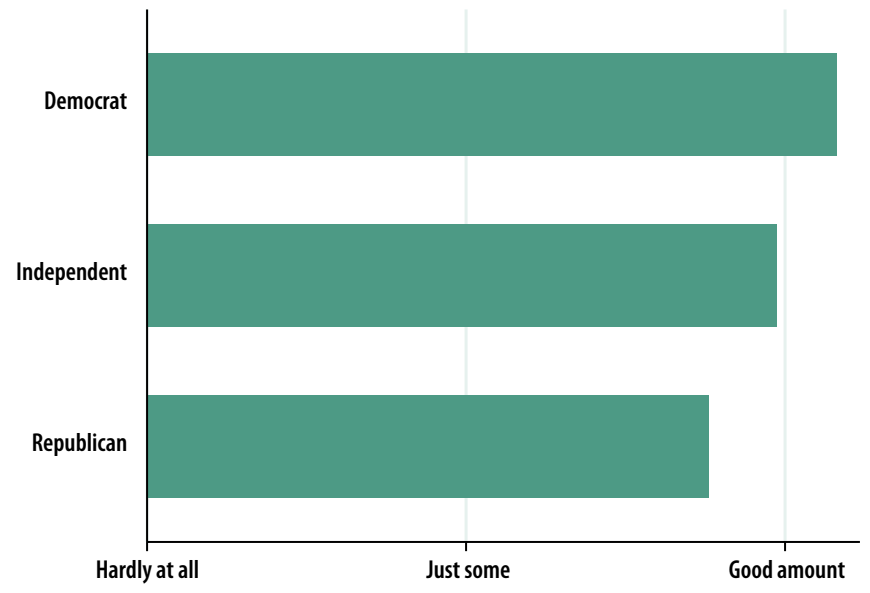

Figure 3B: Mercury contamination of seafood

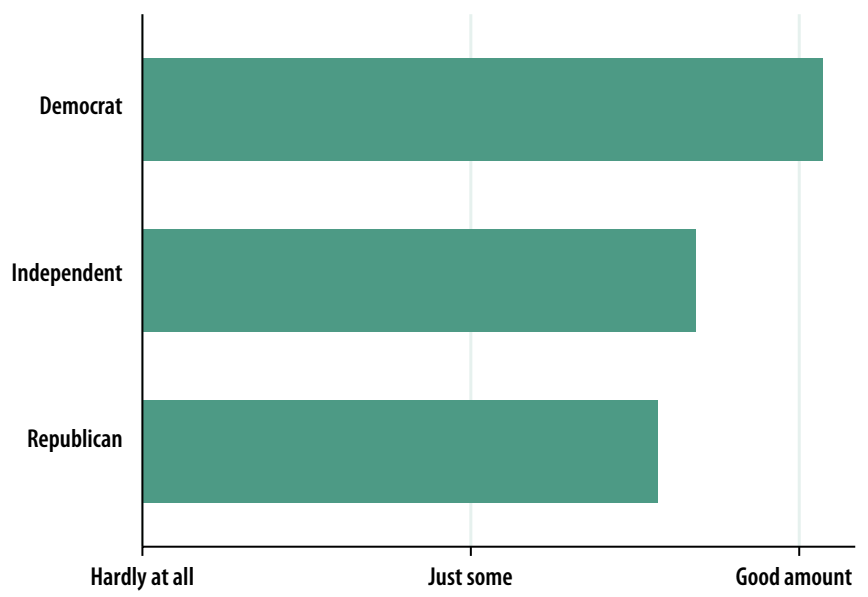

Figure 3C: Depletion of fish through overfishing

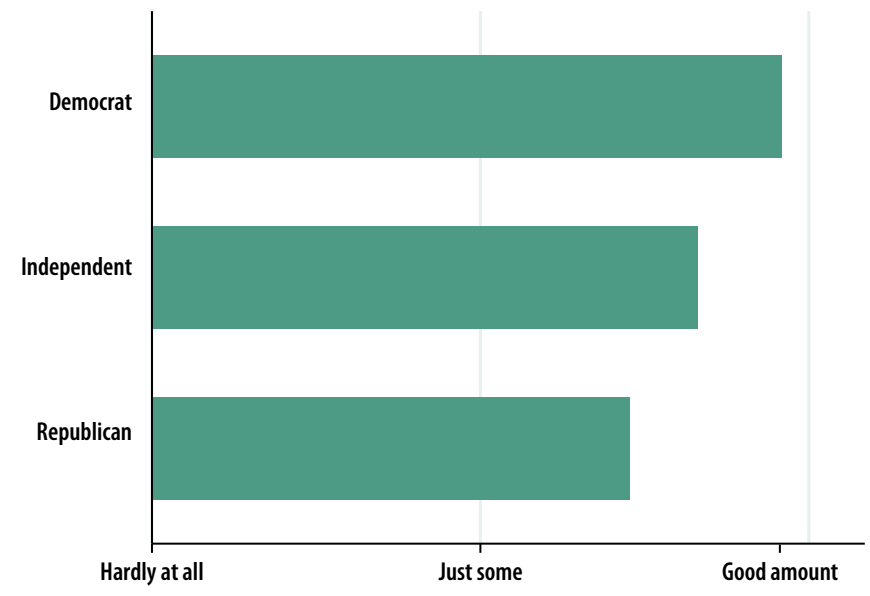

Figure 3D: Rise in sea level due to climate

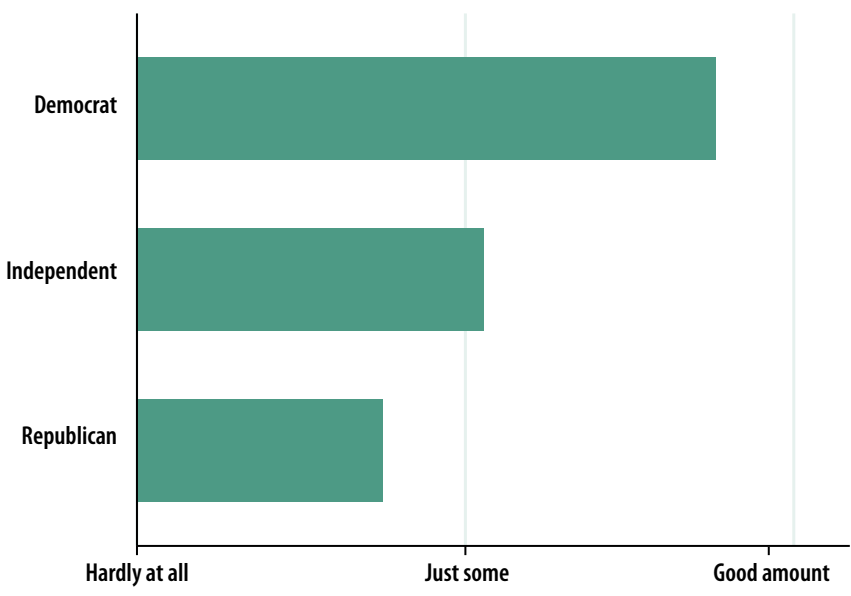

Figure 3E: Environment/scenic impacts of aquaculture

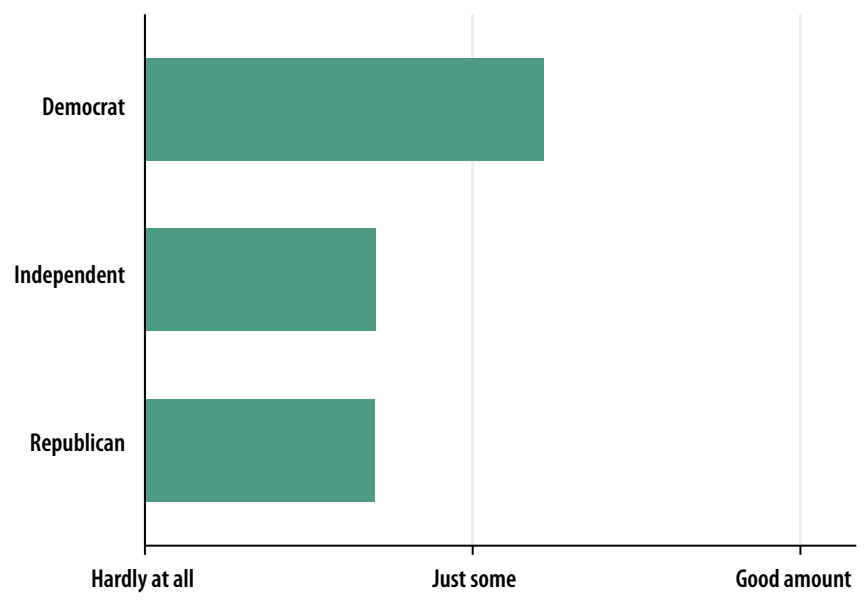


Figure 3F: Do YOU BELIEVE THAT GLOBAL WARMING WILL POSE A SERIOUS THREAT TO YOU OR YOUR WAY OF LIFE IN YOUR LIFETIME?

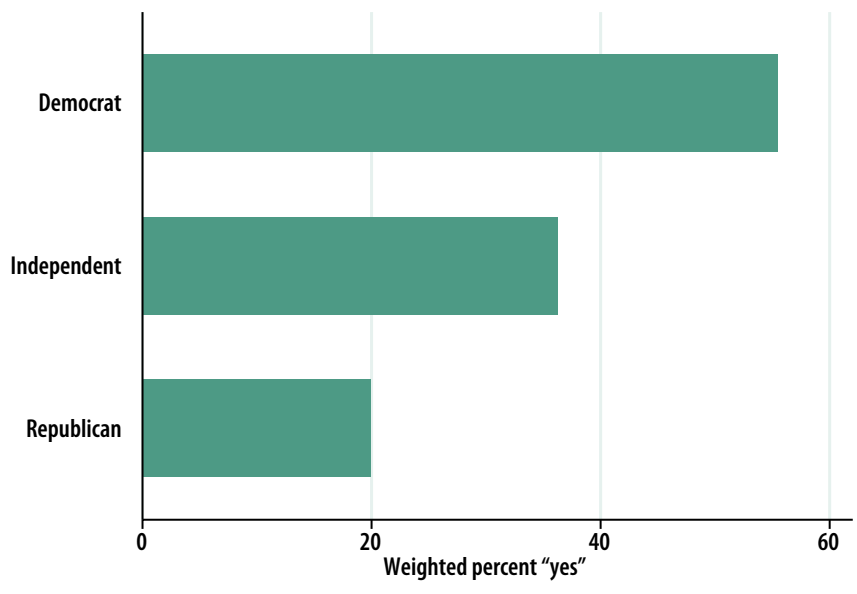

The relationships seen in Figure 3 between political party identification and levels of concern about marine environments remain statistically significant even after we account for age, gender, education, and other background factors. This partisan divide will have implications for policy makers as they seek community-wide participation in responding to both economic and environmental challenges.

\section{Policy Responses to Marine Environmental Concerns}

Survey results in Figures 1, 2, and 3 reveal considerable concern among Downeast residents of all party affiliations about water pollution and the contamination of beaches and clam beds. The greater agreement regarding pollution suggests this is one area where policy makers and community members can find common ground on developing solutions. The considerable concern about loss of fishing jobs and the impacts from overfishing, however, creates a conundrum for fishery managers who want to maintain the economic viability of fishing while also ensuring the sustainability of the resource. The economic downturn in the fishing industry, as well as the depletion of fisheries resources, both seem to call for government intervention. To assess how Downeasters view potential government action, we asked respondents whether they favored more or less government regulation of commercial fishing. Results are in Figure 4.
FIgURE 4: DO YOU THINK THE GOVERNMENT SHOULD DO MORE TO REGULATE COMMERCIAL FISHING AND LOBSTERING, SHOULD IT DO LESS, OR SHOULD IT LEAVE THE RULES AS THEY ARE?

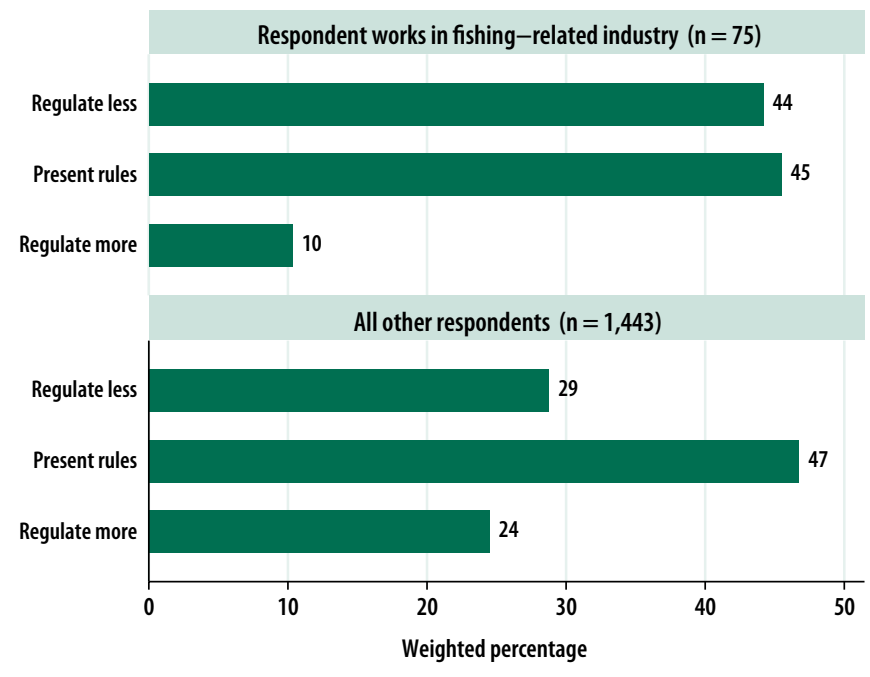

Despite the broad concern about both economic and environmental conditions related to fishing, a majority of respondents believe fishery regulations should remain unchanged. Those who work in fisheries are much more likely than others to believe the government should regulate less. However, relatively few people in the random sample of respondents (fewer than 5 percent) say they or a member of their family works in a fishing-related industry. A minority thinks that additional regulation is needed, but this opinion is more than twice as common among those not involved in fishing-related industries.

Residents in Hancock and Washington counties differ little in their views about fisheries regulation. There are distinctions, however, along party lines. Overfishing and fisheries management have not been prominent in mainstream political discussions, but more versus less government regulation certainly has been. It is therefore perhaps not surprising that the partisan divide over government regulation in general carries over to the specific topic of fisheries, even in places that have experienced firsthand the precipitous declines in fish stocks. Figure 5 illustrates that, as with concerns about overfishing (Figure 3c), party affiliation also strongly influences views on government regulation of fisheries. 
FIGURE 5: DO YOU THINK THE GOVERNMENT SHOULD DO MORE TO REGULATE COMMERCIAL FISHING AND LOBSTERING, SHOULD IT DO LESS, OR SHOULD IT LEAVE THE RULES AS THEY ARE?
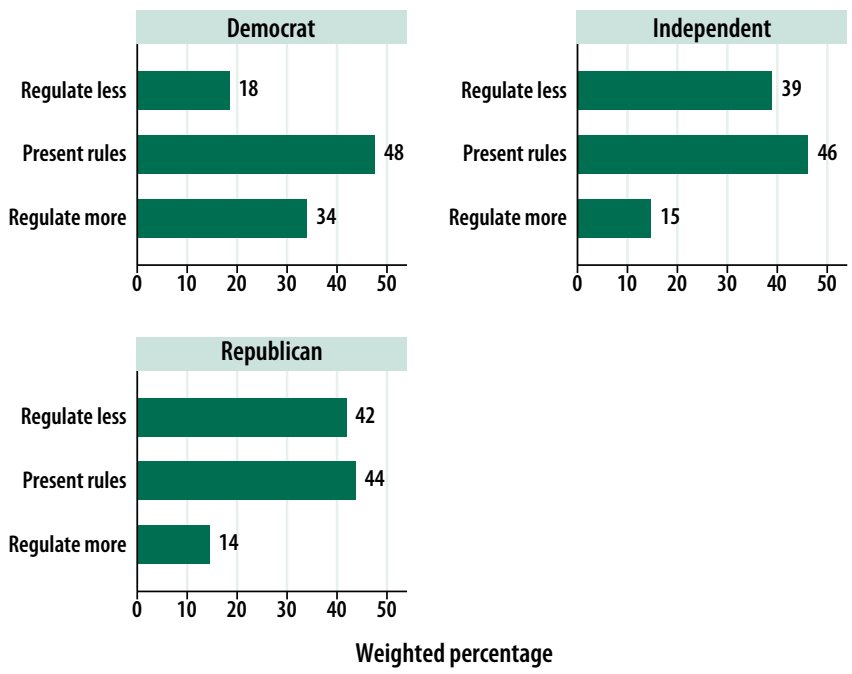

Only 18 percent of respondents who identified with the Democratic Party favor less fisheries regulation, whereas 34 percent favor more. In contrast, 42 percent of Republicans favor less regulation, and only 14 percent favor more. Although there are clear differences in residents' views along party affiliation, the relatively high degree of support for maintaining current fishing rules suggests that government officials should focus on more effectively using existing regulations to achieve socioeconomic as well as conservation goals.

\section{The Future of Rural Coastal Communities in Maine}

The rapid development of coastal areas across the United States has brought significant social and economic change, as well as new environmental problems. Just as traditional agricultural communities have struggled with their new suburban character, rural coastal communities face previously unknown challenges as second-home development and tourism increase. Changes in Downeast Maine are emblematic of these national patterns. The character of this region is still strongly tied to extractive industries, making the loss of fishing or forestry jobs sharply felt. In areas experiencing development, sprawl is increasingly worrisome, as it threatens scenic areas that attract thousands of visitors to the region. Aquaculture is also an important new component of the economy of coastal Maine, and both the environmental and social implications of these operations require further study.

Potential impacts of pollution and seafood contamination are of broad concern. These are areas where civic groups and governmental agencies could find common ground and work toward addressing the sources. Fishing-related issues, on the other hand, appear more divisive and challenging. Fishing's importance economically and culturally underlines the potential troubles raised by overfishing and the impacts of extractive activities on marine ecosystems. The survey results indicate that although there is general opposition to additional regulations, most Downeast residents prefer to maintain existing fishery management regimes. This leaves open the door for policy makers and community groups to work within existing regulatory frames to devise novel solutions to the economic and environmental challenges related to fishing.

In recent years, federal, state, and local managers have struggled to find a model for managing fisheries that meets the needs of fishing communities and sustains marine ecosystems. Increased community engagement and local input into management activities and decision making has been proposed as a pathway to more effective solutions. At the present time, the National Marine Fisheries Service is working with fishermen and community and governmental leaders in the region to forward new "area management" approaches that would directly engage fishers in devising and overseeing locally relevant management strategies within existing regulatory frameworks. ${ }^{19}$ The CERA results appear encouraging for this approach given that Downeast Maine residents and those involved in fishery-related industries, in particular, oppose additional government regulation of fishing.

Finally, one of the most challenging aspects of social and environmental change in Downeast Maine is the emerging partisan divide. Growing polarization in public support for environmental protection has been apparent on national surveys since the late 1990s, as campaigns by conservative political leaders and activists have reshaped environmental issues, such as climate change and land conservation, into political wedge issues. Arguments against taking climate change seriously, in particular, became the focus of hundreds of conservative-movement documents, accompanied by press conferences, policy forums, media presentations, and congressional testimony. ${ }^{20}$ Our Maine survey suggests that the national campaigns are having local impacts. That opinions about regional problems as diverse as contamination of seafood, overfishing, and loss of scenic beauty fall along partisan lines suggests that the national dialogue shapes opinions about not only global issues, such as climate change, but also community-level concerns, such as beach pollution.

For local leaders and policy makers, this division introduces new challenges as they attempt to engage communities in addressing environmental problems. A partisan divide regarding the importance of regulation in the management of marine fisheries is not surprising. However, the observations that overfishing and seafood contamination are becoming 
partisan issues suggests that efforts to merely educate individuals about the existence of environmental problems will not be enough to build consensus on solving them. Government efforts promoting local engagement in environmental management may have greater success given that they build on shared values regarding the social and natural character of coastal Maine communities. Ongoing research under the CERA initiative will continue to map this terrain, examining realities and perceptions about socioeconomic and environmental change in these and other rural coastal communities.

\section{Endnotes}

1. K. M. Crossett et al., Population Trends along the Coastal United States: 1980-2008 (Silver Spring, MD: National Oceanic and Atmospheric Administration, 2004).

2. U.S. Ocean Commission, An Ocean Blueprint for the 21st Century: Final Report of the U.S. Commission on Ocean Policy. Report to the U.S. Congress (Washington, DC: U.S. Ocean Commission, 2004).

3. The initial stages of CERA research were supported by grants from the W. K. Kellogg, Ford, and Mary K. Reynolds Babcock Foundations and by the Neil and Louise Tillotson Fund of the New Hampshire Charitable Foundation. A 2008 report on the survey results, Place Matters: Challenges and Opportunities in Four Rural Americas, is available from the Carsey Institute Web site. Research articles using CERA data include the following: $\mathrm{L}$. C. Hamilton, C. R. Colocousis, and C. M. Duncan, "Place Effects on Environmental Views," forthcoming in Rural Sociology; L. C. Hamilton, "Education, Politics and Opinions about Climate Change: Evidence for Interaction Effects," forthcoming in Climatic Change; L. C. Hamilton and B. D. Keim, "Regional Variation in Perceptions about Climate Change," International Journal of Climatology, Digital Object Identifier: 10.1002/joc.1930 (2009).

4. U.S. Census Bureau, "2006-2008 American Community Survey 3-Year Estimates” (Washington, DC: U.S. Census Bureau, 2009).

5. Ibid.

6. U.S. Census Bureau, "Historical Census of Housing TablesVacation Homes" (Washington, DC: U.S. Census Bureau, 2009), available at www.census.gov/hhes/www/housing/census/historic/ vacation.html.

7. Rural Policy Research Institute, "Demographic and Economic Profile: Maine" (Columbia, MO: Rural Policy Research Institute, 2006); Crossett et al., Population Trends.

8. M. Hall-Arber et al., "New England's Fishing Communities." Massachusetts Institute of Technology Sea Grant College Program 01-15. (Cambridge, MA: Massachusetts Institute of Technology Sea Grant College Program, 2001).

9. Maine Department of Marine Resources, Historical Maine Cod Landings. (Augusta: Maine Department of Marine Resources, 2009), available at www.maine.gov/dmr/commercialfishing/ historicaldata.htm.
10. A. A. Rosenberg et al., "Rebuilding U.S. Fisheries: Progress and Problems," Frontiers in Ecology and the Environment, vol. 4, no. 6 (2006): 303-308.

11. Food and Agriculture Organization of the United Nations, The State of World Fisheries and Aquaculture (Rome: Food and Agriculture Organization, 2009).

12. Maine Department of Marine Resources, Preliminary 2006-2008 Maine Landings Commercial Fishery Ex-Vessel Value By County (Augusta: Maine Department of Marine Resources, 2009), available at www.maine.gov/dmr/commercialfishing/ recentlandings.htm.

13. Ibid.

14. Maine Department of Marine Resources, Maine Aquaculture Review. (Battelle: West Bootbay Harbor, ME: Maine Department of Marine Resources/Normandeau Associates, 2003).

15. R. A. Hites et al., "Global Assessment of Organic Contaminants in Farmed Salmon," Science, vol. 303 (2004): 226-229; M. Krkolšek et al., "Epizootics of Wild Fish Induced by Farm Fish," Proceedings of the National Academy of Sciences, vol. 103, no. 2 (2006): 15506-15510.

16. Maine Department of Health and Human Services, "Report of the Interstate Workgroup on Evaluating Atlantic Coastal Advisories for Recreationally Caught Striped Bass and Bluefish Based on the PCBs (Augusta: Maine Department of Health and Human Services, 2008), available at www.maine.gov/DHHS/ eohp/fish/9_08Final.pdf; Maine Department of Environmental Protection, "Mercury in Maine: A Status Report Prepared for the Joint Standing Committee of the Maine Legislature Having Jurisdiction over Natural Resources" (Augusta: Maine Department of Environmental Protection, 2002), available at www.state.me.us/ $\mathrm{dep} /$ mercury/reports.htm.

17. L. J. Osher et al., "Heavy Metal Contamination from Historic Mining in Upland Soil and Estuarine Sediments of Egypt Bay, Maine, USA," Estuarine Coastal and Shelf Science, vol. 70 (2006):169-179; S. Moore, "The Taunton Bay Assessment: A Report to the Maine Legislature Marine Resources Committee for Consideration of the 2000-2005 Dragging Prohibition" (West Boothbay Harbor: Maine Department of Marine Resources, 2004)

18. Ibid.; Hall-Arber et al., "New England's Fishing Communities."

19. P. Pinto da Silva and A. Kitts, "Collaborative Fisheries Management in the Northeast US: Emerging Initiatives and Future Directions," Marine Policy, vol. 30 (2006): 832-841.

20. R. E. Dunlap and A. M. McCright, "A Widening Gap: Republican and Democratic Views on Climate Change," Environment (September/October, 2008). 


\section{A C K N OW LE D G M E N T S}

The authors would like to thank Chris Colocousis for his work on this project, as well as Megan Henly and Will Buxton for their research assistance.

\section{ABOUT THE AUTHORS}

Thomas G. Safford is a Carsey Institute faculty fellow and an assistant professor of sociology at the University of New Hampshire (tom.safford@unh.edu).

Lawrence C. Hamilton is a Carsey Institute senior fellow and a professor of sociology at the University of New Hampshire (lawrence.hamilton@unh.edu).

\section{UNIVERSITY}

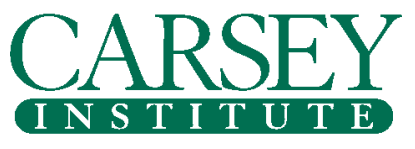

Building knowledge for families and communities

The Carsey Institute conducts policy research on vulnerable children, youth, and families and on sustainable community development. We give policy makers and practitioners timely, independent resources to effect change in their communities.

This work was supported by the Ford Foundation.

Huddleston Hall

73 Main Street

Durham, NH 03824

(603) $862-2821$

www.carseyinstitute.unh.edu 